\title{
EFFICIENCY OF REMOVING ORGANIC POLLUTANTS FROM WASTEWATER IN A HOUSEHOLD WASTEWATER TREATMENT PLANT WITH A HYBRID REACTOR
}

\author{
Michał Marzec ${ }^{1}$ \\ 1 Department of Environmental Engineering and Geodesy, University of Life Sciences in Lublin, Leszczyńskiego \\ 7, 20-069 Lublin, Poland, e-mail: michal.marzec@up.lublin.pl
}

Received: 2016.08.01 Accepted: 2016.09.26 Published: 2016.11.01

\begin{abstract}
The purpose of the study is to evaluate the efficiency of removing organic pollutants from wastewater in a household wastewater treatment plant with a hybrid reactor. The efficiency of the plant was analysed in terms of decreasing $\mathrm{BOD}_{5}, \mathrm{COD}$ and the content of total suspended solids in differentiated technological conditions. The variable parameter was the length of the reactor aeration phase and the dwell phase. Six different aeration variants were analysed. The efficiency of a wastewater treatment plant with a hybrid reactor in terms of reducing $\mathrm{BOD}_{5}$ oscillated from 81 to $90 \%$, COD $-64-84 \%$, whereas total suspended solids $-66-89 \%$ which, as a rule, was not sufficient to achieve standard levels. The best results were achieved for the following variants: $2 \mathrm{~h}$ aeration $-2 \mathrm{~h}$ dwell and $1 \mathrm{~h}$ aeration $-0.5 \mathrm{~h}$ dwell. Lower efficiency of the plant could have been attributed to operational problems, mainly failures of the plant control system and uneven conditions such as air temperature, volume and composition of wastewater received in the plant.
\end{abstract}

Keywords: wastewater treatment, hybrid reactor, $\mathrm{BOD}_{5}, \mathrm{COD}$, TSS.

\section{INTRODUCTION}

Among numerous onsite wastewater treatment plant solutions offered in the market the so-called hybrid plants combining active sludge and trickling filter methods are of significance. Biomass present in two forms, and in particular settled in the trickling filter, is deemed a safety buffer making it possible for these systems to achieve high efficiency of removing pollutants even when the volume and composition of the received wastewater is variable. This provides an opportunity for using such systems in onsite wastewater treatment plants that are often exposed to uneven inflow of wastewater [Abbasi et al. 2000; Fouad and Bhargava 2005; Hannah et al. 2005; Krzanowski and Wałęga 2008; Makowska and Kolanko 2005].

Hybrid systems are much more resistant to hydraulic overload and can receive larger loads of pollutants than classic systems with regard to the possibility of accumulating more biomass in two forms. They also prevent a loss of biomass for large hydraulic overloads, in particular in onsite systems with a low throughput capacity [Makowska and Kolanko 2005]. The intensity of biochemical processes occurring during wastewater treatment in hybrid reactors, and thus the efficiency of removing pollutants, are closely connected with the amount of biomass in the reactor and its growth rate. These parameters are determined by process conditions, among other things, its intensity and method [Abbasi et al. 2000; Fouad and Bhargava 2005]. Currently, studies are carried out into hybrid reactors using variable aeration, which fosters the coexistence of both aerobic and anaerobic conditions inside the reactor, stimulating the growth of various cultures of bacteria. Thus, carbon compounds and biogenic compounds - mainly nitrogen - 
can be removed simultaneously [Yoo et al. 1999; Hanhan et al. 2005].

This work aims at evaluating the efficiency of removing organic pollutants from wastewater in a TRYBIO household wastewater treatment plant with a hybrid reactor. The efficiency of the plant was analysed in terms of decreasing $\mathrm{BOD}_{5}, \mathrm{COD}$ and the content of total suspended solids in technological conditions differentiated in terms of the length of the wastewater aeration cycle in the reactor.

\section{MATERIALS AND METHODS}

The said wastewater treatment plant is located in Dys (Lublin voivodeship) and it has operated since June 2013. It is used for treatment of domestic wastewater from two houses inhabited by five people. The maximum throughput capacity of the plant amounts to $1.0 \mathrm{~m}^{3} \cdot \mathrm{d}^{-1}$. The actual hydraulic load of the plant is considerably lower - about $0.35-0.40 \mathrm{~m}^{3} \cdot \mathrm{d}^{-1}$.

The tank of the TRYBIO plant is made of concrete. It consists of four chambers with the total active capacity of $5.57 \mathrm{~m}^{3}$ [ZWB Wojciech Trykacz 2009]. The first two chambers are primary settling tanks $\left(\mathrm{V}_{\mathrm{cz}}=3.36 \mathrm{~m}^{3}\right)$, the third chamber $\left(\mathrm{V}_{\mathrm{cz}}=\right.$ $1.57 \mathrm{~m}^{3}$ ) is the hybrid reactor operating based on activated sludge and immersed trickling filter sys-

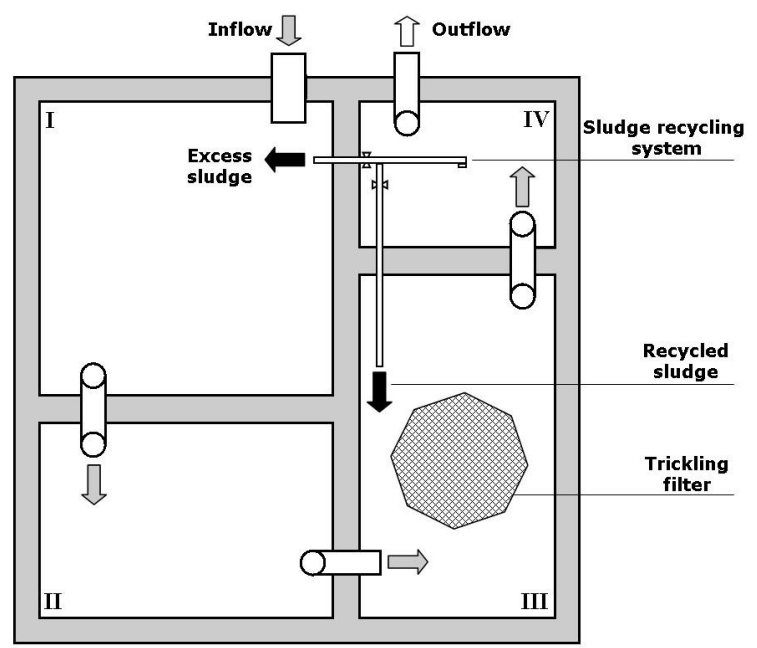

Figure 1. Schematic of a TRYBIO household wastewater treatment plant with a hybrid reactor (horizontal section): I, II - chambers of the primary settling tank, III - hybrid reactor (activated sludge and trickling filter), IV - secondary settling tank [ZWB Wojciech Trykacz 2009; Jóźwiakowski et al. 2012] tem, and the fourth chamber $\left(\mathrm{V}_{\mathrm{cz}}=0.64 \mathrm{~m}^{3}\right)$ contains a secondary settling tank (Fig. 1).

In the primary settling tank solids are separated and the accumulated sludge is initially fermented. From the second chamber of the primary settling tank wastewater flows into the hybrid reactor where it is cleaned by means of the biological activated sludge method (suspended biomass) and immersed trickling filter (settled biomass). The trickling filter with the capacity of $0.225 \mathrm{~m}^{3}$ is fitted with plastic packing. Suspended and settled biomass is supplied with oxygen by means of a diaphragm blower and a disc diffuser [ZWB Wojciech Trykacz 2009; Marzec et al. 2011]. The last element of the plant is a secondary settling tank from which cleaned wastewater flows to the drainage system. Some sludge retained inside the secondary tank is from time to time recycled into the reactor by means of an airlift pump to ensure a fixed concentration of biomass. The rest is discharged into the first chamber of the primary settling tank (Fig. 1).

The pollutant removing efficiency of a treatment plant with a hybrid reactor was analysed in differentiated technological conditions. The variable parameter was the length of the reactor aeration phase and the dwell phase. Six different reactor aeration variants were analysed during the study term: $\mathbf{I}$ : aeration $-2 \mathrm{~h}$, dwell - 2h (2h-2h); II: aeration - 1h, dwell - $1 \mathrm{~h}$ (1h-1h); III: aeration $-1 \mathrm{~h}$, dwell $-2 \mathrm{~h}$ (1h2h); IV: aeration - 1h, dwell - 3h (1h-3h); V: aeration $-2 \mathrm{~h}$, dwell $-1 \mathrm{~h}(2 \mathrm{~h}-1 \mathrm{~h})$; VI: aeration $-1 \mathrm{~h}$, dwell $-0,5 \mathrm{~h}$ (1h-0,5h). Each variant was analysed for 5 weeks.

Samples for physical and chemical analyses were taken every week from the first chamber of the primary settling tank (raw wastewater) and from the outlet of the secondary settling tank (wastewater after biological treatment). According to applicable methods [Hermanowicz et al. 1999], the following indicators were determined in the samples: temperature, $\mathrm{pH}, \mathrm{BOD}_{5}$ and $\mathrm{COD}_{\mathrm{Cr}}$, total suspended solids and in addition - the concentration of dissolved oxygen, nitrogen and total phosphorus.

Based on the results, characteristic values were determined for the above-mentioned indicators along with the effects of removing pollutants for each of the analysed variants of biological reactor aeration. The results of analyses were 
compared with the requirements set forth in the Regulation of the Minister of Environment issued in 2014 [Dz. U. 2014, poz. 1800].

\section{RESULTS AND DISCUSSION}

Hybrid wastewater treatment plants are considered resistant to highly variable hydraulic loads and pollutant loads, mainly thanks to the presence and utilisation of microorganisms occurring in two forms: active sludge (suspended biomass) and bio-diaphragm (settled biomass) [Abbasi et al. 2000; Fouad and Bhargava 2005; Hannah et al. 2005]. In TRYBIO hybrid plants the bio-diaphragm develops on a fixed-bed trickling filter immersed in wastewater. The analyses carried out at the plant tested its efficiency in terms of removing basic pollutants such as: total sus- pended solids and organic pollutants expressed as $\mathrm{BOD}_{5}$ and $\mathrm{COD}_{\mathrm{Cr}}$. The removal of such pollutants is closely connected with the intensity of conversion of nitrogen and phosphorus. In turn, it is determined by the concentration of oxygen dissolved in wastewater. Therefore, the quality of treated wastewater and the efficiency of a TRYBIO hybrid plant were tested for different lengths of the reactor aeration phase and the dwell phase. Selected results of the survey are presented in Table 1.

The composition of raw wastewater received by the facility during the term of analyses was quite varied. The $\mathrm{pH}$ of wastewater ranged from 7.38 to 8.37 . Wastewater sampled from the primary settling tank was characterised by a relatively low content of total suspended solids, clearly lower than indicated in reference literature [Heidrich 1998]. Over the entire study period the concen-

Table 1. Characteristic values of pollution indicators in raw wastewater and in wastewater treated

\begin{tabular}{|c|c|c|c|c|c|c|c|}
\hline \multirow{4}{*}{\multicolumn{2}{|c|}{ Parameters }} & \multicolumn{6}{|c|}{ Reactor aeration variants } \\
\hline & & $\begin{array}{c}\mathrm{I} \\
(2 \mathrm{~h}-2 \mathrm{~h}) \\
\end{array}$ & $\begin{array}{c}I I \\
(1 \mathrm{~h}-1 \mathrm{~h})\end{array}$ & $\begin{array}{c}\text { III } \\
(1 \mathrm{~h}-2 \mathrm{~h})\end{array}$ & $\begin{array}{c}\text { IV } \\
(1 \mathrm{~h}-3 \mathrm{~h})\end{array}$ & $\begin{array}{c}\mathrm{V} \\
(2 \mathrm{~h}-1 \mathrm{~h})\end{array}$ & $\begin{array}{c}\mathrm{VI} \\
(1 \mathrm{~h}-0,5 \mathrm{~h})\end{array}$ \\
\hline & & \multicolumn{6}{|c|}{$\frac{\text { Min-Max }}{\text { Mean }}$} \\
\hline & & \multicolumn{6}{|c|}{ Raw wastewater } \\
\hline Temperature & {$\left[{ }^{\circ} \mathrm{C}\right]$} & $\frac{14,2-18,8}{16,7}$ & $\frac{11,1-16,0}{13,7}$ & $\frac{10,5-14,3}{12,4}$ & $\frac{8,0-13,2}{9,9}$ & $\frac{5,9-12,9}{10,3}$ & $\frac{14,1-18,6}{16,6}$ \\
\hline $\mathrm{pH}$ & & $7,50-7,84$ & $7,64-8,24$ & $7,38-8,02$ & $7,87-8,23$ & $7,82-8,37$ & $7,61-7,90$ \\
\hline Dissolved oxygen & {$[\mathrm{mg} / \mathrm{l}]$} & $\frac{0,10-0,23}{0,17}$ & $\frac{0,10-0,32}{0,18}$ & $\frac{0,1-0,2}{0,16}$ & $\frac{0,16-0,44}{0,25}$ & $\frac{0,2-0,28}{0,23}$ & $\frac{0,23-0,34}{0,31}$ \\
\hline TSS & {$[\mathrm{mg} / \mathrm{l}]$} & $\frac{117-225}{165}$ & $\frac{8-168}{86,3}$ & $\frac{84-306}{195,4}$ & $\frac{88-316}{187,6}$ & $\frac{2.6-160}{89,3}$ & $\frac{112-165}{137}$ \\
\hline $\mathrm{BOD}_{5}$ & {$\left[\mathrm{mgO}_{2} / \mathrm{l}\right]$} & $\frac{350-447}{405}$ & $\frac{166-509}{400}$ & $\frac{147-450}{340}$ & $\frac{387-609}{512}$ & $\frac{140-556}{379}$ & $\frac{142-309}{245}$ \\
\hline $\mathrm{COD}_{\mathrm{Cr}}$ & {$\left[\mathrm{mgO}_{2} / \mathrm{I}\right]$} & $\frac{610-730}{682}$ & $\frac{360-870}{718}$ & $\frac{380-940}{664}$ & $\frac{710-1030}{864}$ & $\frac{540-1030}{810}$ & $\frac{330-570}{430}$ \\
\hline Total nitrogen & {$[\mathrm{mg} / \mathrm{l}]$} & $\frac{118-192}{143}$ & $\frac{55-166}{120}$ & $\frac{111-146}{127}$ & $\frac{109-144}{128}$ & $\frac{124-145}{137}$ & $\frac{75-109}{86}$ \\
\hline \multirow[t]{2}{*}{ Total phosphorus } & {$[\mathrm{mg} / \mathrm{l}]$} & $\frac{15,4-21,0}{17,84}$ & $\frac{7,6-24,0}{17,30}$ & $\frac{5,18-19,25}{14,23}$ & $\frac{13,6-16,8}{15,00}$ & $\frac{10,6-20,0}{14,58}$ & $\frac{10,1-15,5}{12,60}$ \\
\hline & & \multicolumn{6}{|c|}{ Treated wastewater } \\
\hline Temperature & {$\left[{ }^{\circ} \mathrm{C}\right]$} & $\frac{14,2-18,0}{16,5}$ & $\frac{11,5-16,6}{13,6}$ & $\frac{10,3-13,9}{12,1}$ & $\frac{6,7-12,6}{9,3}$ & $\frac{6,0-13,0}{9,9}$ & $\frac{14,1-18,2}{16,1}$ \\
\hline $\mathrm{pH}$ & & $7,51-8,07$ & $7,98-8,20$ & $7,93-8,15$ & $8,10-8,28$ & $8,04-8,24$ & $7,57-7,92$ \\
\hline Dissolved oxygen & {$[\mathrm{mg} / \mathrm{l}]$} & $\frac{3,14-3,89}{3,46}$ & $\frac{0,13-3,37}{2,13}$ & $\frac{0,75-3,3}{2,23}$ & $\frac{0,41-3,42}{1,25}$ & $\frac{0,24-2,38}{1,05}$ & $\frac{0,21-3,51}{1,27}$ \\
\hline TSS & {$[\mathrm{mg} / \mathrm{l}]$} & $\frac{9,6-103}{55,8}$ & $\frac{13,3-30,6}{18,8}$ & $\frac{2,3-38}{21,1}$ & $\frac{6,3-54,9}{26,8}$ & $\frac{2,17-42,3}{19,3}$ & $\frac{7,2-22}{15,5}$ \\
\hline $\mathrm{BOD}_{5}$ & {$\left[\mathrm{mgO}_{2} / \mathrm{l}\right]$} & $\frac{16,1-83}{40,8}$ & $\frac{36-137}{64,6}$ & $\frac{20-93,6}{69,2}$ & $\frac{66-102,4}{84,9}$ & $\frac{27-132}{70,8}$ & $\frac{7,9-60,8}{28,5}$ \\
\hline $\mathrm{COD}_{\mathrm{Cr}}$ & {$\left[\mathrm{mgO}_{2} / \mathrm{l}\right]$} & $\frac{65-142}{108,8}$ & $\frac{121-310}{221}$ & $\frac{190-280}{238}$ & $\frac{230-290}{270}$ & $\frac{160-290}{230}$ & $\frac{50-230}{140}$ \\
\hline Total nitrogen & {$[\mathrm{mg} / \mathrm{l}]$} & $\frac{75-87}{79}$ & $\frac{98-131}{109}$ & $\frac{91-126}{108}$ & $\frac{101-126}{111}$ & $\frac{104-139}{125}$ & $\frac{12-72}{40}$ \\
\hline Total phosphorus & {$[\mathrm{mg} / \mathrm{l}]$} & $\frac{2,5-15,1}{11,72}$ & $\frac{10,1-16,9}{13,72}$ & $\frac{4,76-16,5}{12,79}$ & $\frac{9,6-15,2}{12,98}$ & $\frac{12,6-18,1}{14,44}$ & $\frac{0,80-9,50}{5,83}$ \\
\hline
\end{tabular}


tration of suspended solids only sporadically exceeded $300 \mathrm{mg} \cdot \mathrm{dm}^{-3}$. On average it amounted to $144 \mathrm{mg} \cdot \mathrm{dm}^{-3}$ (Table 1 ). Slightly higher values, closer to typical levels, were recorded for organic pollutant indicators $-\mathrm{BOD}_{5}$ and $\mathrm{COD}_{\mathrm{Cr}}$. For the first one the average value over the entire period of study exceeded $380 \mathrm{mgO}_{2} \cdot \mathrm{dm}^{-3}$, and sporadically it was close to $500 \mathrm{mgO}_{2} \cdot \mathrm{dm}^{-3}$. At the same time, $\mathrm{COD}_{\mathrm{Cr}}$ oscillated within a very wide range from 330 to $1030 \mathrm{mgO}{ }_{2} \cdot \mathrm{dm}^{-3}$ (on average slightly above $700 \mathrm{mgO}_{2} \cdot \mathrm{dm}^{-3}$ ). Such a differentiated composition of raw wastewater is characteristic of most rural households. It is due to many factors, mainly of social, economic and technical nature [Heidrich 1998]. In addition, mutual relations between the indicators, and in particular $\mathrm{COD}: \mathrm{BOD}_{5}, \mathrm{BOD}_{5}: \mathrm{N}$ and $\mathrm{BOD}_{5}: \mathrm{P}$ are very significant in terms of correct course of the treatment process [Heidrich et al. 2008]. The ratio COD: $\mathrm{BOD}_{5}$ in the analysed samples of raw wastewater was equivalent to the optimum level $(\leq 2.2)$. Relations between other ratios should be, respectively: $\mathrm{BOD}_{5}: \mathrm{N} \geq 4, \mathrm{BOD}_{5}: \mathrm{P} \geq 25$ [Heidrich et al. 2008]. In most wastewater samples analysed they were too low, which means that the supply of nitrogen and phosphorus compounds is too high compared to the content of organic compounds. At the same time, it must be taken into account that a considerable part of organic substances is found in suspended solids [Heidrich et al. 2008], so the relations between the indicators analysed in the wastewater subject to biological treatment could have been even less favourable.

The quality of wastewater discharged from the secondary settling tank was highly variable. The $\mathrm{pH}$ was not significantly different from that of raw wastewater. The content of total suspended solids in treated wastewater was low. In single cases it exceeded the level acceptable for small treatment plants (Table 1). The highest values of the parameter were noted down at the beginning of the plant's operation (variant I). At that time, the average efficiency of the plant in removing suspended solids was slightly above $66 \%$ (Fig. 2). The high content of suspended solids at the beginning of the plant's operation can be related to the process of sludge seeding. At high concentrations of active sludge and insufficient capacity of the recirculation system sludge floated onto the surface of wastewater in the secondary settling tank from which samples were taken for laboratory tests. At subsequent stages of the analyses, the efficiency of eliminating suspended solids increased to $80-90 \%$, and the average value of the parameter for variants II-VI did not exceed $30 \mathrm{mg} \cdot \mathrm{dm}^{-3}$ (Table 1 ).

The most representative indicators of wastewater quality are $\mathrm{BOD}_{5}$ and $\mathrm{COD}$. In case of $\mathrm{BOD}_{5}$ a very large discrepancy between results in respective series of tests is worth noting. In all variants the average efficiency of removing organic pollutants expressed by this indicator oscillated around $80-90 \%$ (Fig. 2). Despite this fact, only for variant I and VI the average value of $\mathrm{BOD}_{5}$ was higher than or close to the acceptable level [Dz. U. 2014, poz. 1800]. In other cases, it clearly exceeded this level (Table 1). In respective series of tests the indicator in treated wastewater often exceeded the limit of $80 \mathrm{mgO}_{2} \cdot \mathrm{dm}^{-3}$.

A similar trend can be observed for $\mathrm{COD}_{\mathrm{Cr}}$ where the time variation curve of the indicator

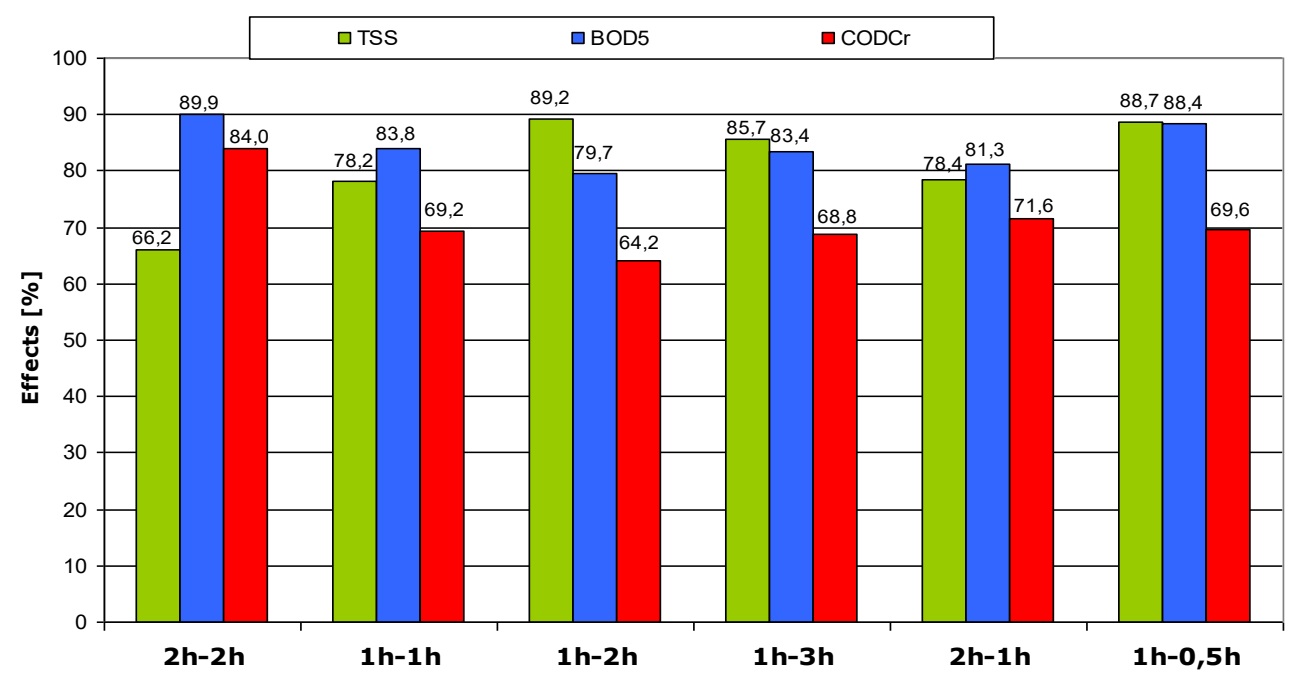

Figure 2. Average efficiency of removing basic pollutants for respective variants of hybrid reactor aeration 
was similar to that for $\mathrm{BOD}_{5}$. During the tests of variant I ( $2 \mathrm{~h}-2 \mathrm{~h}), \mathrm{COD}_{\mathrm{Cr}}$ was below the level described as acceptable. During tests of variants II, III, IV and V (1h-1h, 1h-2h, 1h-3h, 2h-1h), COD clearly exceeded $200 \mathrm{mgO}_{2} \cdot \mathrm{dm}^{-3}$, and was often close to $300 \mathrm{mgO} \cdot \mathrm{dm}^{-3}$ (Table 1). For variant VI of biological reactor aeration (1h$0.5 \mathrm{~h}$ ) improved quality of treated wastewater and a decrease in COD below $100 \mathrm{mgO}_{2} \cdot \mathrm{dm}^{-3}$ were noted down. The highest average efficiency of removing organic pollutants expressed as COD, that is, nearly $85 \%$, was recorded for variant I (2h-2h). For other variants the average efficiency of the treatment plant in reducing COD did not exceed $70 \%$ (Fig. 2).

The quite high variation of results prevents an unambiguous evaluation of the operation of a TRYBIO hybrid plant and the selection of the optimum variant of biological reactor aeration. This is because the efficiency of removing pollutants in such facilities, apart from aeration of wastewater in the reactor, is affected by many other, equally significant factors. The tests have shown that the level of elimination of organic pollutants was the highest for a two-hour reactor aeration phase and two-hour dwell (variant I) and one-hour aeration and thirty-minute dwell (variant VI). This fact can be closely connected with removing biogenic compounds - nitrogen and phosphorus - from wastewater since heterotrophic microorganisms responsible for their ultimate elimination from wastewater, that is, denitrifiers and phosphorus accumulating bacteria, will uti- lize organic compounds in wastewater as an external source of carbon [Yoo et al. 1999; Hanhan et al. 2005]. The efficiency of removing both nitrogen and total phosphorus in the said treatment plant was definitely the highest in variant I and VI of hybrid reactor aeration (Fig. 3), which could be conditioned by the temperature of wastewater. The optimum temperature for correct removal of nitrogen and phosphorus from wastewater is above $16^{\circ} \mathrm{C}$ [Obaja et al. 2003]. Tests of respective variants, with regard to their duration, were carried out at various temperatures. Only for variant I and VI the average temperatures of wastewater exceeded $16^{\circ} \mathrm{C}$. In other cases they ranged from $9.9^{\circ} \mathrm{C}$ to $13.7^{\circ} \mathrm{C}$ (Table 1 ).

Apart from temperature, oxygen conditions and their variability are significant for the correct conversion of nitrogen and phosphorus in the wastewater, including correct activity of denitrifying and phosphorus accumulating bacteria. In the hybrid reactor they are shaped by adequate selection of intensity and length of reactor aeration phases [Mazumder and Dikshit 2004]. The optimum concentration of oxygen in the aeration zone, as given in reference literature, should not exceed $2.5 \mathrm{mgO}_{2} \cdot \mathrm{dm}^{-3}$ [Yoo et al. 1999]. In the analysed reactor aeration variants the concentration of dissolved oxygen was determined in treated sewage. The average value of this parameter oscillated about $1-2 \mathrm{mgO}_{2} \cdot \mathrm{dm}^{-3}$, whereas in variant I it reached $3.46 \mathrm{mgO}_{2} \cdot \mathrm{dm}^{-3}$ (Table 1). These values are not reliable but it can be supposed that the content of oxygen in a hybrid

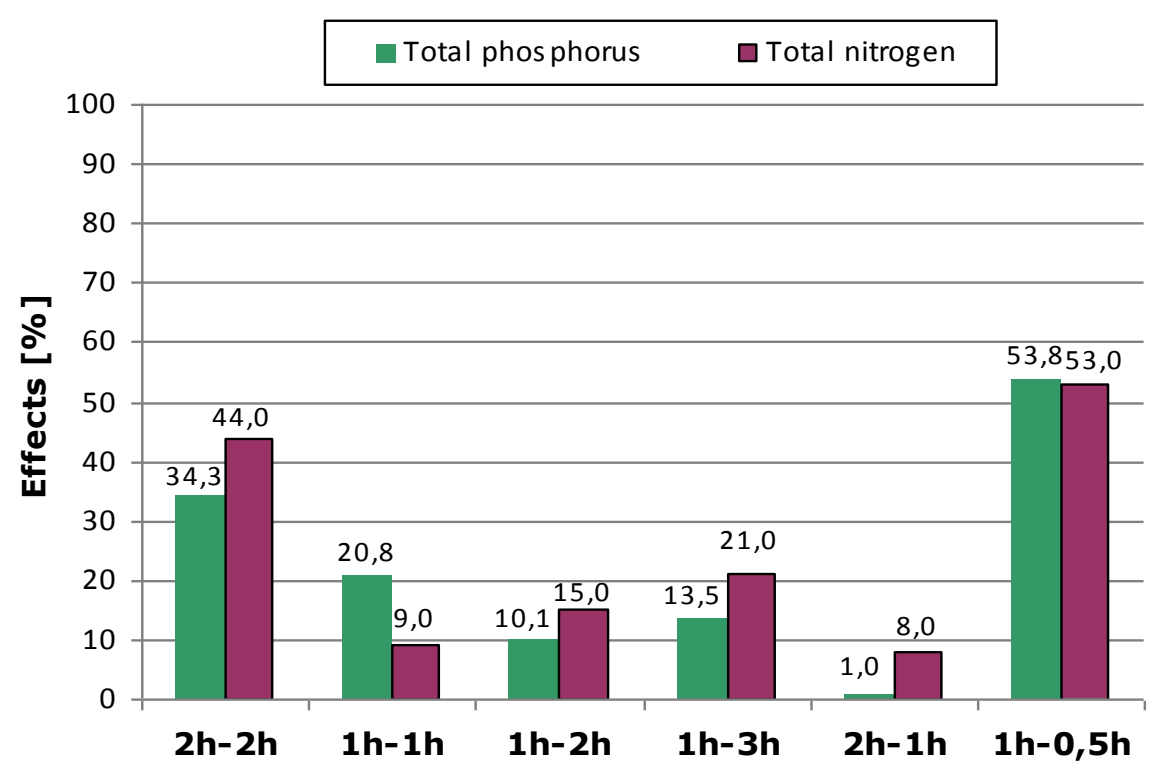

Figure 3. Average efficiency of total nitrogen and phosphorus removing for respective variants of hybrid reactor aeration 
reactor, in particular at the aeration phase, was considerably higher. With regard to the fact that the content of organic compounds in treated sewage is quite high, it is likely that the concentration of oxygen could be a factor limiting the process of reduction of nitrogen compounds and accumulation of phosphorus.

The analysed wastewater treatment system makes it possible to remove organic pollutants efficiently but it requires a more advanced system of controlling conditions inside the reactor and increasing the recirculation of sludge from the secondary settling tank. In this context it should be mentioned that in the study period several operational issues occurred, including single cases of failure of the time switch controlling the process of wastewater aeration in the hybrid reactor and recirculation of wastewater and active sludge. Such a defect can cause, for example, destruction of active sludge in the reactor [Bugajski and Ślizowski 2004] and even if quickly removed, it can affect the process of treatment and the quality of wastewater flowing out of the facility.

\section{CONCLUSIONS}

1. The efficiency of a TRYBIO household wastewater treatment plant with a hybrid reactor in terms of reducing $\mathrm{BOD}_{5}$ oscillated from 81 to $90 \%$, COD $-64-84 \%$, whereas total suspended solids $-66-89 \%$ which, as a rule, was not sufficient to achieve standard levels set for such indicators.

2. The best effects of removing organic pollutants expressed as $\mathrm{BOD}_{5}$ and $\mathrm{COD}$ were achieved for the following variants: aeration $-2 \mathrm{~h}$, dwell $-2 \mathrm{~h}$ and aeration $-1 \mathrm{~h}$, dwell $-0.5 \mathrm{~h}$.

3. Removal of organic pollutants from wastewater in the treatment plant with a hybrid reactor was dependent on the dynamics of conversion of nitrogen and phosphorus compounds and indirectly on the thermal and oxygen conditions inside the reactor.

4. Highly differentiated indicators of efficiency for respective variants of analyses result from the fact that the analyses were carried out in field conditions and over a long period of time, which is connected with a considerable differentiation of conditions, including ambient temperature, volume and composition of wastewater received in the plant.
5. Providing an efficient system of control to maintain the optimum technological conditions and signal emergencies is the fundamental condition for efficient operation of onsite wastewater treatment plants with a hybrid reactor.

\section{REFERENCES}

1. Abbasi B., Dullstein S., Raebiger N. 2000. Minimalization of excess sludge production by increase of oxygen concentration in activated sludge flocs; experimental and theoretical approach. Wat. Res., 34, 1, 139-146.

2. Bugajski P., Ślizowski R. 2004. Ocena działania małej oczyszczalni ścieków z osadem czynnym w świetle aktualnie obowiązujących przepisów. Inżynieria Rolnicza. 2, 175-184.

3. Fouad M., Bhargava R. 2005. Sludge production and settleability in biofilm-activated sludge process. Journal of Environmental Engineering ASCE, 3, 417-424.

4. Hanhan O., Artan N., Orhon D., Yagci N.O., Insel G. 2005. Mechanism and design of intermittent aeration activated sludge process of nitrogen removal. IWA Specialized conference on Nutrient Management in Wastewater Treatment Process and Recycle Streams. LEM-TECH Konsulting, Kraków, 69-78.

5. Heidrich Z. Przydomowe oczyszczalnie ścieków. Poradnik. 1998. Centralny Ośrodek Informacji Budownictwa, Warszawa.

6. Heidrich Z., Kalenik M., Podedworna J., Stańko G. 2008. Sanitacja wsi. Wyd. Seidel-Przywecki, Warszawa.

7. Hermanowicz W., Dojlido W., Dożańska W., Koziorowski B., Zerbe J. 1999. Fizykochemiczne badanie wody i ścieków. Arkady, Warszawa.

8. Jóźwiakowski K., Marzec M., Pytka A., Gizińska M., Goral R. 2012. Dokumentacja techniczna budowy przydomowej hybrydowej oczyszczalni ścieków w miejscowości Dys. Lublin.

9. Krzanowski S., Wałęga A. 2008. Effectiveness of organic substance removal in household conventional activated sludge and hybryd treatment plants. Enviroment Protection Engineering, Vol. 34, 3, 5-12.

10. Makowska M., Kolanko H. 2005. Kinetyka przyrostu biomasy w reaktorach hybrydowych. Roczniki AR w Poznaniu, Melior. Inż. Środ., 26, 257-265.

11. Marzec M., Jóźwiakowski K., Trykacz W., Goral R. 2011. Budowa i zasada działania przydomowych oczyszczalni ścieków typu TRYBIO. Gospodarka odpadami komunalnymi. Monografia pod red. K. Szymańskiego, T. VII, 231-242. 
12. Mazumder D., Dikshit A.K. 2004. Hybrid reactor system for wastewater treatment - application and approach of modelling. International Journal of Environment and Pollution, 21, 2, 105-131.

13. Obaja D., Macé S., Costa J., Sans C., Mata-Alvarez J. 2003. Nitrification, denitrification and biological phosphorus removal in piggery wastewater using a sequencing batch reactor. Biores. Technol., 87, 103-111.

14. Rozporządzenie Ministra Środowiska z dnia 18 listopada 2014 r. w sprawie warunków, jakie należy spełnić przy wprowadzaniu ścieków do wód lub do ziemi, oraz w sprawie substancji szczególnie szkodliwych dla środowiska wodnego (Dz.U. 2014, poz. 1800).

15. Yoo H., Ahn K.H., Lee H.J., Kwak Y.J., Song K.G. 1999. Nitrogen removal from synthetic wastewater by simultaneous nitrification and denitryfication (SND) via nitrite in an intermittently - aerator reactor. Wat. Res., 33, 1, 145-152.

16. Zakład Wyrobów Betonowych Wojciech Trykacz. 2009. Instrukcja montażu i obsługi oczyszczalni TRYBIO. Łucka.

Pracę dofinansowano ze środków Wojewódzkiego Funduszu Ochrony Środowiska i Gospodarki Wodnej w Lublinie. 